Relations industrielles

Industrial Relations

\title{
Bruce, Christopher J., and Jo Carby-Hall, Rethinking Labour-Management Relations: The Case for Arbitration
}

\section{Terry H. Wagar}

Volume 48, numéro 2, 1993

URI : https://id.erudit.org/iderudit/050861ar

DOI : https://doi.org/10.7202/050861ar

Aller au sommaire du numéro

Éditeur(s)

Département des relations industrielles de l'Université Laval

ISSN

0034-379X (imprimé)

1703-8138 (numérique)

Découvrir la revue

Citer ce compte rendu

Wagar, T. H. (1993). Compte rendu de [Bruce, Christopher J., and Jo Carby-Hall, Rethinking Labour-Management Relations: The Case for Arbitration]. Relations industrielles / Industrial Relations, 48(2), 365-366.

https://doi.org/10.7202/050861ar

Tous droits réservés @ Département des relations industrielles de l'Université Laval, 1993
Ce document est protégé par la loi sur le droit d'auteur. L’utilisation des services d'Érudit (y compris la reproduction) est assujettie à sa politique d'utilisation que vous pouvez consulter en ligne.

https://apropos.erudit.org/fr/usagers/politique-dutilisation/ 
Rethinking Labour-Management Relations: The Case for Arbitration, (by Christopher J. Bruce and Jo Carby-Hall, New York, Routledge, 1991, 206 p., ISBN 0-415-002213-4

In this book, Bruce and Carby-Hall argue that interest arbitration is preferred to the strike as a means of resolving labour-management conflict. The first four chapters of the book focus on the strike-based system while the remaining five chapters address various issues relating to interest arbitration.

In Chapter 1, the authors review the evolution of the strike-based system. They assert that a successful industrial relations system must provide workers with some form of collective voice, be implementable in the face of concerted opposition from both employers and government, and take a form that could rally a wide cross-section of workers. Chapter 2 provides a summary of the relationship between collective bargaining and collective voice, efficiency, equity and legal structuring.

In Chapter 3, the strike-based system is reviewed with particular attention on bargaining power, whether there is a fundamental right to strike, and the deficiencies of the strike-based system. Chapter 4 addresses possible modifications to the strike-based system such as restrictions on the use of replacement workers, secondary industrial action, union democracy, and statutory strikes (in which production continues but the employees do not receive wages and employer profits are taxed).

In the fifth chapter, a taxonomy of arbitration systems is developed. Among the points for discussion are the legal structure for arbitration, concerns relating to arbitrators (number, selection, payment of fees), the role of mediation, the provision of information (government agency to provide statistical data, information about arbitrators' preferences), the selection procedure (conventional and final offer arbitration), and settlement (panel decisions, publication of the decision).

In Chapter 6, the focus is on the role of arbitration. The authors conclude that arbitration is preferable to the strike-based system when examining collective voice, efficiency, equity and legal structuring arguments. They also tackle potential problems with arbitration including partiality of the arbitrator, discouragement of bargaining in good faith, and enforcement of the arbitrator's award.

The seventh chapter examines the market for arbitration. The authors believe that some form of government compulsion would be necessary to get the parties to move from a free market or strike-based system; they favour a competitive private arbitration system in which the parties are able to choose their own arbitrators and the arbitration awards are published. They also support permitting the parties to select the dispute resolution procedures (to meet particular industry conditions, increase commitment to the process, and permit alterations as industrial relations changes occur) but penalty provisions should be established by government because of the effect of work stoppages on third parties.

The British experience with wage councils is reviewed in Chapter 8 and the authors conclude that a wage council system is not an appropriate model for collective bargaining and dispute resolution.

In Chapter 9, the authors propose a compulsory arbitration system. The major components of such a system would include: (1) the right of the parties to select their 
own dispute-resolution procedures, (2) government or state involvement in the selection of a special dispute resolution procedure for industries or occupations in which workers are not sufficiently well organized to establish procedures themselves; in addition, the procedures will apply to all aspects of the employment relationship; (3) resolution of the dispute must be either strike or arbitration and parties wishing to use the strike approach must obtain permission from an independent commission; (4) penalties against parties defying a no-strike or lockout provision; and (5) retaining conciliation services.

The book is well written and the arguments of the authors are presented in a logical manner. In addition, the authors support their position with considerable reference to the empirical and theoretical literature from Canada, the United States, Britain and Australia. Individuals unfamiliar with the literature on arbitration could develop a good bibliography merely by referencing the notes provided at the end of the book.

While scholars of interest arbitration will probably find that the book covers a lot of familiar ground, the authors achieve their objective of contributing to the review of the forms of collective bargaining. Although the book contains insights worthy of consideration by practitioners, it will probably be of more interest to academics. The authors could provide more discussion and analysis of some of the drawbacks associated with interest arbitration as well as elaborate on potential union resistance to their proposals. Nevertheless, the authors don't simply hide behind the cloak of recommending interest arbitration; rather, they outline the elements which should be contained in legislation. Despite the rather extensive literature on interest arbitration and strikes, a careful reading of this book raises several important questions and underscores the need for more research on dispute resolution.

Terry H. WAGAR

Saint Mary's University

Markets, Firms and the Management of Labour in Modern Britain, by Howard F. Gospel, Cambridge, UK, Cambridge University Press, 1992, 256 p., ISBN 0-521-41527-6

This book examines the development of labour management in Britain from the late nineteenth century up to the present time. It deals with employers' human resource and industrial relations policies in a broad historical perspective, focusing on how managers organize the employment relationship, how they control work relations and how they deal with trade unions and industrial relations. These three major topics are examined in three historical periods: late nineteenth century, twentieth century up to the second world war and post-war years. They are analyzed in the context of the product and labour markets within which the firm operates, and the strategy, structure, and hierarchy of the modern industrial enterprise.

The purpose of the book is to explore five propositions that influence labour management decisions. Markets for both labour and final products are key independent variables influencing labour management decisions. Corporate strategies and structures are significant intervening variables shaping strategy and structure in the labour field. The 